\title{
Urodimento
}

REVISTA DE ESTUDOS EM ARTES CÊNICAS

E-ISSN 2358.6958

\section{Ode ao teatro musicado nacional em quatro etapas, um prólogo e um epílogo}

\author{
Larissa de Oliveira Neves
}

Para citar este artigo:

NEVES, Larissa de Oliveira. Ode ao teatro musicado nacional em quatro etapas, um prólogo e um epílogo. Urdimento - Revista de Estudos em Artes Cênicas, Florianópolis, v. 2, n. 41, set. 2021.

do) DOI: http:/dx.doi.org/10.5965/1414573102412021e0104

Este artigo passou pelo Plagiarism Detection Software| iThenticate 


\title{
Ode ao teatro musicado nacional em quatro etapas, um prólogo e um epílogo 1
}

Larissa de Oliveira Neves²

\begin{abstract}
Resumo
Este artigo apresenta o caminho histórico do abrasileiramento da opereta e da revista de ano até a composição de gêneros de palco novos, a burleta e a revista carnavalesca, a fim de pontuar sua extrema importância para a constituição do teatro brasileiro. Trata-se da exposição deste percurso, de maneira a demonstrar a ampla motivação musicada do teatro brasileiro de todos os tempos e como, na verdade, o teatro musicado popular nunca foi um tipo periférico de arte cênica, quando comparado com o teatro "literário", ou "moderno", mas, sim, consiste no centro, no motivador, sendo talvez o gênero mais proeminente, da conformação do teatro nacional.
\end{abstract}

Palavras-chave: Teatro musicado. História do teatro brasileiro. Gêneros teatrais.

\section{Ode to the national musical theater in four steps, a prologue and an epilogue}

\begin{abstract}
This article presents the historical path of the "brazilianness" of operetta and "end of the year revue", to the composition of new stage genres, in order to point out its extreme importance for the constitution of Brazilian theater. The paper presents this path in order to demonstrate the immense musical motivation of Brazilian theater of all times and how, in fact, popular musical theater was never a peripheral type of scenic art when compared to "literary" or "modern" theater, but it is the center, the motivator, perhaps the most prominent theatre genre for the conformation of the national theatre.
\end{abstract}

Keywords: Musical theater. History of Brazilian theatre. Theatrical genres.

${ }^{1}$ Artigo fruto de pesquisa financiada pela Fapesp.

2 Pós-Doutorado pela Université Sorbonne Nouvelle (Paris 3) (2016), e Universidade Estadual de Campinas Unicamp (2008-09). Doutorado em Teoria e História Literária pela Universidade Estadual de Campinas (Unicamp - 2006), mestrado em Teoria e História Literária pela mesma Universidade (2002). Professora de dramaturgia, história e teoria do teatro no Departamento de Artes Cênicas, Instituto de Artes, Unicamp (SP), desde março de 2009. Larissan@unicamp.br

(3ttp://lattes.cnpq.br/6238228710475915 (1) https://orcid.org/0000-0001-7183-4078 


\section{Ode al teatro musical nacional en cuatro fases, um prólogo e un epílogo}

\section{Resumen}

Este artículo presenta el camino histórico del "abrasileramento" de la opereta y de la revista de año, hasta la composición de nuevos géneros escénicos, con el fin de señalar su extrema importancia para la constitución del teatro brasileño. Se trata de levantar esta ruta con el fin de demostrar la amplia motivación musical del teatro brasileño de todos los tiempos y cómo, de hecho, el teatro musical popular no es un tipo periférico de arte escénico en comparación con el teatro "literario" o "moderno", pero, sí, es el centro, el motivador, tal vez el más prominente tipo de teatro para la conformación del teatro nacional.

Palabras-clave: Teatro musical. Historia del teatro brasileño. Géneros teatrales. 


\section{Nota de Apresentação}

Tenho pesquisado o teatro musicado brasileiro ${ }^{3}$ por muitos anos, em especial as operetas oitocentistas. Uma vez uma amiga me disse: "tudo começou com a opereta". A frase ficou retumbando em minha cabeça. Tudo o quê? A reposta foi me vindo no decorrer do tempo: "tudo - simplesmente tudo."

O presente artigo visa estruturar o pensamento que aos poucos se constituiu, para mim, neste "tudo" - o antes e o depois do teatro brasileiro é intrinsecamente ligado ao teatro musicado, aos diversos tipos de teatro musicado popular: fato que a historiografia não pode compreender até o final do século XX. Nossa "única tradição teatral” seria comédia de costumes (Cf. Prado, 1999, p.117). Seria? Sem dúvida é uma delas. Mas também o teatro musicado, que não foi considerado tradição por causa do olhar obnubilado dos críticos de então. Trata-se de um fato que apenas os pesquisadores efetivos do teatro musicado puderam vislumbrar ${ }^{4}, a$ exemplo de Neyde Veneziano: "Nossa tradição teatral permite afirmar que o teatro de revista foi o gênero mais expressivo do teatro brasileiro" (Veneziano, 2010, p.9). O teatro musicado é uma das vertentes mais poderosas do teatro brasileiro, e, mesmo assim, ou talvez por isso mesmo, foi durante décadas relegado ao estigma do "mero entretenimento".

Ao abordar em um projeto que os gêneros musicados de palco chegaram até nós pelas companhias estrangeiras (francesas e portuguesas especialmente), mas que no começo do século XX esses já haviam se tornado totalmente nacionais, em forma, estrutura, enredos, etc., tornando-se, então, gêneros novos, um leitor me disse que valia e pena eu mencionar o artigo em que defendo essa ideia. Então percebi que o artigo não existe, eu nunca o tinha escrito. Citei naquele projeto, como não poderia deixar de fazer, Neyde Veneziano (1991), que fez o estudo sobre

\footnotetext{
${ }^{3}$ Utilizo aqui o termo "teatro musicado" seguindo talvez uma linha mais histórica que aparecia nos estudos, no sentido de um conceito "guarda-chuva", que abarcaria várias ramificações. "O Teatro Musicado [...] inclui todos os gêneros previamente escritos com canções e pensados, antecipadamente, para serem representados por atores-cantores. [...] Diversos gêneros de teatro musicado tornaram-se muito expressivos no Brasil: como a opereta, o teatro de revista, o vaudeville, a burleta." (Guinsburg; Faria; Lima (org.), 2006. p. 190-191).

${ }^{4}$ Para citar alguns dentre tantos possíveis: Reis e Marques (In. Faria, 2012); Chiaradia (2012); Rabetti (2007), Mencarelli (1999; 2003), Costa-Lima Neto (2014); Almeida (2016); etc.
} 
o abrasileiramento da revista e sobre a revista carnavalizada nacional; mas ampliar sua tese para o teatro musicado como um todo consiste em algo antes não registrado em artigo, embora talvez todas as pessoas que trabalhem com teatro musicado percebam essa verdade e a explorem de diferentes maneiras.

Aqui se pretende abordar, portanto, em quatro etapas, a constituição histórica dessa verdade que só muito recentemente a academia vem permitindo evidenciar, porque o teatro musicado, assim como outros gêneros de teatro popular, esteve durante muitas décadas relegado a uma marginalidade. Somente por meio das leituras recentes, a partir da precursora Veneziano e de diversos outros pesquisadores que seguiram as trilhas abertas nos anos 1980 e 1990, sendo eu um deles, as universidades passaram a olhar tais gêneros com os olhos desvelados, retiradas as correntes que impunham normas estilísticas europeias para a constituição do que seria válido em termos de teatro e de literatura dramática. Correntes rompidas, ou em processo de, podemos hoje retraçar a caminhada do teatro musicado de modo a mostrar sua real validade e importância para a história do teatro nacional - mais importante que romantismo, realismo, simbolismo, etc. - sim, mais importante.

Assim, o presente artigo não visa ser um estudo de caso, de período, de artistas, de peças, de gêneros musicados - visa registrar o que já sabemos, mas que ainda não localizamos em nenhum estudo específico - uma demonstração histórica de que "tudo começou com a opereta" (e com suas irmãs e primas).

\section{Prólogo ou: antes do teatro popular musicado, o Brasil se fez em teatralidade musicada popular}

O teatro brasileiro é tão ambíguo, confuso e bagunçado ${ }^{5}$ quanto sua própria história e cultura. País colonizado, cuja cultura foi formada pela combinação e transformação de diversas matrizes culturais, o Brasil tornou-se uma nação onde podemos encontrar pessoas com expressões culturais semelhantes vivendo em regiões muito distantes (em especial ressalto aqui as festas e folguedos presentes em todos os estados brasileiros com especificidades próprias em cada região) e,

${ }^{5}$ Para usar aqui a noção de Alcântara Machado - o teatro bagunça (Machado, 2009, p.377). 
ao mesmo tempo, diferenças notáveis entre os modos de vida de habitantes de diferentes estados. A interação (não-pacífica) entre europeus, indígenas e africanos durante alguns séculos deu origem a uma nova cultura - a brasileira (Cf. Ribeiro, 1995; Schwarcz e Starling, 2015). Apesar da violência dessa história, ou por causa dessa violência, as pessoas conseguiram criar belas festas populares, danças e músicas, que expressam, sim, sua alegria de viver e de estar juntos, mas que também são uma forma de sobreviver e de lutar. Sobreviver à dura rotina diária de escravidão, manter sua identidade, lutar direta e indiretamente contra opressores.

As festas e folguedos ${ }^{6}$ populares do Brasil são arte, alegria e diversão. Não menos importante, são uma de nossas formas mais marcantes de resistência não só identitária, mas também política (os folguedos serviam como forma de comunicação, como ocorre por exemplo no jongo ${ }^{7}$, ou de habilidades de luta, como ocorre na capoeira). Essas magníficas manifestações artísticas foram por décadas ou consideradas sem importância, ou ignoradas, ou repreendidas por instituições governamentais e acadêmicas no país. É válido falar sobre teatro musicado brasileiro a partir deste pano de fundo, porque nesses espaços se conformaram danças, músicas, corporeidades, linguagens cênicas que viriam a servir de mote para o teatro musicado de palco.

Por mais delicado que seja abordar o assunto, o Brasil é um país onde os escravizadores e os escravizados encontraram alguns lugares comuns na cultura popular: o rancho de reis invade a casa do senhor, como vemos na peça Uma véspera de reis, de Arthur Azevedo (2002). Esse fato torna difícil explicar nossa cultura e como funciona a interação entre as pessoas no país. Em alguns estudos mais antigos, do começo do século XX, a violência e o preconceito foram de certa maneira minimizados por uma falsa ideia de mistura pacífica de culturas (Cf. Holanda, 2016; Freyre, 1973). A mistura é real, o aspecto pacífico não o é. A forma

\footnotetext{
${ }^{6}$ Utilizo folguedos ao invés de brincadeiras ou danças dramáticas para referenciar autores(as) que tenho lido e estudado no decorrer de anos de pesquisa sobre a cultura popular nacional. O termo é utilizado por pesquisadores e folcloristas, embora exista uma discussão atual sobre o mesmo, que prefere o termo brincadeira.

O jongo não é apenas um ritmo e dança afro-brasileiro, é uma manifestação religiosa e também de luta direta contra os capatazes em fazendas, já que os versos codificados serviam não apenas para a festa, mas também e talvez principalmente para organizar combinações, fugas e revoltas contra os senhores das fazendas. Site do IPHAN - http://portal.iphan.gov.br/pagina/detalhes/59 Acesso em: 02 maio 2021.
} 
como o povo brasileiro combate as injustiças de seu país é desafiadora de se compreender, mas nem por isso menos assertiva.

O teatro musicado de palco surgiu baseado em formas europeias que, quando apresentadas por companhias de teatro estrangeiras no Rio de Janeiro, ganharam grande visibilidade entre a classe artística e literária. Quase imediatamente artistas brasileiros perspicazes, sendo vários negros e mestiços, ligados ao popular, à rua, e também às casas de espetáculo, que então eram redutos elitistas, modificaram as estruturas teatrais estrangeiras ao incluir hábitos, expressões e músicas brasileiras em traduções e adaptações que se desenvolveram rapidamente, tornando-se cada vez mais recheadas de costumes, palavras, canções, danças populares nacionais, a ponto de, no início do século XX, serem formas de arte completamente forjadas nas corporeidades e musicalidades daqui, cujas estruturas de cena só poderiam ser encontradas no Brasil ${ }^{8}$.

Os espetáculos eram baseados no dia a dia da cidade, com cenas que se referiam aos problemas das pessoas, seus trabalhos, suas formas de se relacionar, etc. Eles se calcavam também na música, na dança, na temática, nas formas de expressão corporal, nas máscaras que fazem parte das festividades populares mais ou menos teatrais comuns em várias regiões do país. Esse tipo de teatralidade aconteceu (e ainda acontece) nas ruas, em festas religiosas, em praças. Mais recentemente apresentam-se também em espaços mais regrados, criados especialmente para as festas, como os sambódromos, bumbódromos ou quadrilhódromos ${ }^{9}$. As folias não apresentam apenas tipos específicos de música e danças brasileiras, mas algumas delas são formas incrivelmente complexas de teatro com personagens, enredos, máscaras e improvisação (a exemplos das festas do boi ou dos desfiles de carnaval).

As festas e folguedos eram os espaços de representação teatral formado e apresentado no Brasil colônia. São formas de espetáculos que não ganhavam

${ }^{8}$ Neyde Veneziano (2013) analisou esse percurso de abrasileiramento em relação ao teatro de revista.

9 Weslley Fontenele (2020) aborda o caminho da rua para o quadrilhódromo nas festas do boi de Parnaíba (PI), no artigo "O Bumba-meu-Boi de Parnaíba (PI) em diferentes espaços: a rua, a arena e as lives juninas". Grácia Navarro e Andréa Martini (2017) abordam a criação dos sambódromos no artigo "Carnaval Brasileiro: do legado colonial à pluralidade de linguagens na contemporaneidade brasileira - o caso do Bloco BerraVaca!" 
registros escritos. Suas poesias, canções, belos textos eram aprendidos, criados e transmitidos oralmente. Os atuantes são chamados de "brincantes", porque brincam, se divertem, dançam, atuam num tipo de aquisição de saber e de treinamento muito diferente daquele mais comum ao do ator e da atriz de teatro. Os folguedos e brincadeiras sempre usam a música para conceber suas estruturas de cena. Alguns são inteiramente musicais, alguns alternam momentos de fala ou versos com momentos de canto (Cf. Andrade, 1982; Cascudo, 2002).

Não houve interesse por parte de uma elite política portuguesa e brasileira em instituir um teatro em estilo europeu no Brasil durante quatro séculos, entre 1500 e 1800; ou houve pouquíssimo interesse, por parte dos governantes do país, ou da elite letrada brasileira (a maioria sendo súditos do imperador de Portugal) em instigar a formação de um teatro em estilo "ocidental" nas terras nacionais ${ }^{10}$. Assim, as poucas companhias daqui encenavam peças de origem ibérica e as formas mais vibrantes de encenação eram as brincadas nas ruas pelas pessoas escravizadas ou as mais pobres, em torno das quais, nos dias de feriado, se reuniam também as elites.

Quando a corte de Dom João VI se estabeleceu no Rio de Janeiro a partir de 1808, os primeiros teatros grandes passaram a ser construídos. Após a proclamação da independência, dramaturgos brasileiros começaram a difundir seus textos e a encená-los nestes teatros. Urgia diferenciar o país independente do país colonizador. Alguns dos primeiros dramaturgos observaram que o Brasil tinha formas espetaculares de teatro sendo realizadas em festas e feiras de rua, por isso as projetaram para produzir o tipo de teatro que, desde aquele início, se comunicava com a população brasileira. Era um teatro popular, com música, dança, hábitos e expressões do povo pobre e/ou negro.

Embora todos assistissem e apreciassem como público, essas formas mais próximas do imaginário popular nacional tiveram recepção duramente criticada em áreas literárias, acadêmicas e jornalística, desde os quase contemporâneos daqueles autores - vide textos de José de Alencar (1829-1877) sobre Martins Pena (1815-1843) (Alencar, 1857); ou textos de Coelho Neto (1864-1934) sobre Arthur

10 Para maiores informações, ver os estudos de Mariana Soutto Mayor (2015; 2017). 
Azevedo (1855-1908) (Cf. Neves, 2006); - até o final do século XX - vide textos mais antigos de Décio de Almeida Prado (1917-2000) (Prado, 1971). Mesmo hoje em dia legitimar essas formas de arte como sendo tão preciosas quanto o que podemos chamar de teatro erudito (isto é, aquele que se espelha em modelos literários europeus canônicos e reverenciados) constitui uma forma de luta dentro das universidades, por exemplo.

Embora a música tenha feito parte da dramaturgia brasileira que se inspirava nas festas populares desde que os primeiros autores apareceram, como Martins Pena (Cf. Costa-Lima Neto, 2014), foi na segunda metade do século XIX que o teatro musicado se tornou uma verdadeira febre no Rio de Janeiro e espalhou-se para outras cidades importantes do país.

\section{Primeira etapa: a chegada da opereta francesa}

Ironicamente, os gêneros vieram da França, ou seja, da referência cultural erudita europeia para os brasileiros do século XIX. Romantismo, realismo, naturalismo... a França regia as formas inovadoras de literatura e de teatro e, no Brasil, os autores mais famosos, como José de Alencar e Machado de Assis (18391908), buscavam espelhar-se em tais formas para produzir suas obras ${ }^{11}$. O marco da chegada da opereta, como se sabe, foi a inauguração de um cabaré francês chamado Alcazar Lirique, ocorrida em 1859 no Rio de Janeiro. Antes disso, o teatro lírico francês fora apresentado no Rio de Janeiro por empresas que excursionavam pelas Américas (Cf. Levin, 2014), mas, quando uma empresa francesa se fixou na cidade, o sucesso foi extraordinário.

Eram apresentados, no Alcazar Lirique, os mais recentes sucessos do teatro musicado popular de Paris, especialmente as operetas de Jacques Offenbach (1819-1880), com artistas franceses. Operetas eram espetáculos teatrais que alternavam diálogos cantados e refrões com partes faladas. Na França eram considerados gêneros menores, quando comparados à ópera ou à ópera-cômica - visão que se transplantou na sociedade elitizada carioca. A agilidade dos enredos

${ }^{11}$ Esses dois nomes canônico obtiveram, em seus romances, originalidade formal que extrapolou a inspiração vinda da França. No teatro buscavam mais a fundo alinhar-se ao ideal civilizatório Europeu, tanto em relação às peças que escreviam como aos textos críticos (Cf. Faria, 2001). 
cômicos, a música saltitante e dançante, a ironia, a versatilidade, porém, fizeram com que, apesar das críticas, as operetas do Alcazar adquirissem sucesso estrondoso entre as elites letradas do Rio de Janeiro, que iam ao cabaré para assistir aos grandes sucessos em sua língua original. A historiografia considerou, então, que começou aí uma "decadência” do teatro brasileiro (Cf. Levin, 2014).

As tramas cômicas das operetas francesas geralmente parodiavam temas considerados eruditos e importantes, como a Mitologia Grega ou fatos históricos. Foram consideradas à época o que havia de mais irreverente, inusitado e desordeiro na sociedade parisiense ${ }^{12}$. Eram peças que, apesar de estrangeiras, carregavam em sua estrutura e em seu aspecto turbulento e audacioso uma semelhança instigante com as linguagens cênicas nacionais vivenciadas nas festas e folguedos. As operetas não tinham uma forma rígida, eram maleáveis para se adaptarem ao que agradava ao público; eram fragmentadas; tinham uma vivacidade e uma alegria oriundas da música e da comédia que as tornavam uma ferramenta política bastante importante. Em tais aspectos, o gênero estava próximo ao que as teatralidades de rua nacionais, forjadas naqueles quatro séculos de luta por liberdade das classes escravizadas ou menos favorecidas, apresentavam.

Não foi à toa, portanto, que as operetas praticamente varreram as outras formas europeias de teatro do interesse da população brasileira - quando chegaram não houve mais espaço ou interesse dentre o público para assistir a peças sérias, "elevadas", realistas: o que interessou ao brasileiro, seja o pobre, seja o rico, foi a força de ruptura e a vivacidade artística daquele gênero musical. As operetas apresentavam um alto grau de subversão, sendo censuradas, perseguidas e criticadas intensamente no Brasil e na França. Nesse aspecto, também lidavam com o permitido e o proibido como acontecia com as teatralidades afro-brasileiras.

Alguns dos maiores sucessos no Brasil (e na França) foram Orfeu no Inferno e A bela Helena, ambas com dramaturgia de Ludovic Halévy, Hector Crémieux, música de Jaques Offenbach; e A filha de Madame Angot, com dramaturgia de

12 Para saber mais sobre as caraterísticas do gênero e sua história, ver Neves, 2018. 
Clairville, Victor Koning, Paul Siraudin, música de Charles Lecocq. O número de peças francesas apresentadas, porém, passou de 140 (Cf. Maciel; Rabetti, 2010). Orfeu no Inferno estreou em 1865 no Alcazar Lirique e se tornou um sucesso extraordinário, com 500 apresentações consecutivas. O texto foi quase imediatamente publicado no Brasil também (Levin, 2014).

O público do Alcazar era formado por pessoas de classe média à alta. Apesar das restrições literárias feitas ao gênero da opereta, que eram pontuadas em notícias de jornais, havia o lado chique e esnobe de se assistir em francês às mais recentes novidades do teatro musicado de Paris. Mas, para além desse lado elitista, o fato é que as operetas, com seu caráter de desordem, de rebaixamento, e sua abertura para o hibridismo, incluindo a subversão de temas considerados altos e graves, combinavam com a sociedade brasileira e todas as suas idiossincrasias. Não causa surpresa, portanto, quando olhamos para trás, que um gênero de teatro e de música considerado menor na França, mas com tal potencial para transmitir alegria e para produzir críticas ao mesmo tempo, agradaria tanto ao povo brasileiro.

\section{Segunda etapa: as adaptações brasileiras}

Essa notável repercussão fez com que um ator e dramaturgo brasileiro percebesse que o sucesso das operetas poderia ser trazido para mais perto de todos os habitantes caso se comunicasse com a cultura popular, na língua brasileira, não sendo apresentado apenas como espetáculo estrangeiro, por artistas franceses. O artista que teve essa ideia foi Francisco Correia Vasques (1829-1892). Vasques, comediante que havia trabalhado nas mais importantes companhias de teatro brasileiras, com uma perspicácia só possível a uma pessoa que transitava entre o popular e o erudito, notou o grande potencial que as operetas francesas teriam se fossem abrasileiradas, ou seja, se fossem transformadas em peças que projetavam as formas de teatro de rua, com uso de música brasileira. Ele percebeu, provavelmente não a partir de uma análise, mas sim a partir de seu saber como ator cômico, que a estrutura da opereta facilitava o aproveitamento de hábitos e linguagens cênicas de folia da população em sua estrutura dramática. 
Vasques, que agregava em sua prática de atuação as linguagens teatralizadas da cultura nacional, notou a proximidade dessas formas de artes cênicas com aquele gênero francês que estava encantando e polemizando junto às elites da cidade. Apreendeu que toda a loucura e desordem de um gênero quase renegado pela cultura erudita e sublime francesa, colocado em um lugar marginal em seu país de origem e no Rio de Janeiro, estava em sintonia com a cultura brasileira de uma maneira intensa. Então, ele decidiu adaptar a bem sucedida opereta Orfeu no Inferno aos hábitos brasileiros. Sua peça se chamou Orfeu na roça, estreou na recém fundada companhia Fênix Dramática em 1868 (Prado, 1999), e mudou, para sempre, a forma brasileira de se fazer teatro de palco.

A empresa Fênix Dramática, de Jacinto Heller (1834-1909), tornou-se um importante espaço de divulgação das peças musicadas até o final do século XIX. É interessante constatar que essa companhia se insere no lugar da empresa Ginásio Dramático, onde eram encenadas as sérias peças realistas (Ferreira, 2016)13. O advento dessa companhia, com atores egressos do Ginásio, é quase um paradigma da transformação geral que se iniciava naquele momento - nada mais de dramas ou comédias "para sorrir"14, as empresas passaram a encenar comédias escrachadas, com muita música, alegria, diversão - decadência total, na visão daqueles literatos; não na nossa, é claro. Para nós, começava, aí, um teatro de palco que de fato dialogava com as realidades e a cultura nacional.

O nome mais conhecido deste período foi o de Arthur Azevedo. Chegando de São Luiz do Maranhão, onde nascera, ao Rio de Janeiro, em 1873, com 18 anos de idade, Azevedo encantou-se com o teatro musicado e, também, como Vasques, percebeu que este era o caminho de um teatro nacional que dialogava com a população de maneira firme e intensa. Aliás, ele chegou ao Rio de Janeiro já com uma peça de sucesso que alternava momentos falados com momentos cantados, a graciosa e popularíssima Amor por anexins, de 1870. Em 1876, adaptou para os costumes nacionais dois grandes sucessos do Alcazar: La fille de Madame Angot,

${ }^{13}$ Sobre a empresa do Ginásio Dramático e as peças sérias, ver: Faria, 1993.

14 José de Alencar (1857), no ensaio "A comédia brasileira" faz um manifesto a favor de peças que façam sorrir ao invés de rir. 
que ganhou o título de A filha de Maria $A n g u^{15}$ e La belle Hélène, com título de Abel, Helena. Ambas foram encenadas por Jacinto Heller.

As adaptações se estenderam até o começo do século XX. Não podem ser consideradas traduções, pelo menos não no uso habitual do termo (não se buscava manter certa fidelidade ao original, como em geral consiste no objetivo que as traduções costumam perseguir). Os autores, como Vasques, Azevedo e outros trabalhavam com enorme liberdade, mudando nomes, contextos, ações. Em geral se mantinha o mesmo fio de enredo do original e também as músicas, embora essas fossem intercaladas com composições populares nacionais (canções que vinham das festas e brincadeiras nativas). As mudanças dos títulos, citadas acima, dão ideia de como seguia a adaptação textual e cênica. A repercussão foi enorme: quem assistia às versões francesas deliciava-se com a paródia, quem não assistia igualmente se deleitava ao ver em cena situações cômicas e críticas, personagens e músicas que reconhecia como inspiradas em situações concretas do cotidiano, da vida nacional, da cultura da terra.

A inserção de um ou outro número de música e dança brasileiros nestas adaptações modificavam de forma impactante as estruturas das operetas, embora não chegassem a constituir gêneros novos. Volta e meia surgiam na cena ritmos como lundu, polca, cateretê, maxixe, modinha, entre outros. Pesquisadores da história da música popular atestam que na prática é difícil distinguir tais ritmos, todos incluíam uma base musical com origens africanas e/ou indígenas, misturadas a melodias portuguesas ou espanholas. O termo "lundu" ou simplesmente "batucada" foi muito utilizado para descrever músicas e danças do universo diaspórico brasileiro (Abreu, 1996, p. 55). Certo que ao inserir motes, personagens e, em alguns momentos, corporeidades brasileiras na cena abria-se caminho para uma particularização da opereta, para transformação em algo formalmente novo.

Ao identificar que aquele gênero, a opereta, por tudo que descrevemos acima, diferente de dramas românticos ou realistas (sisudos, sérios, literários até a última vírgula), aquele sim (vibrante, cômico, cênico, maleável), tinha intenções cênico-

15 Um estudo detalhado sobre o abrasileiramento desta peça pode ser acessado em: Neves, 2016. 
musicais que propiciariam algo inusitado e novo na cena nacional; e ao dar o passo seguinte que foi criar enredos, personagens e situações nacionais que se acomodassem àquela estrutura tão propícia ao diálogo com as teatralidades que tínhamos, as linguagens cênicas de rua, de feira e de festa, as teatralidades do "corpo encantado das ruas" brasileiras (Simas, 2020); tais artistas, que foram vários, mas que deixo aqui apenas os nomes dos mais citados (Vasques, Azevedo e Heller), sem consciência de sua importância histórica, iniciavam uma vertente das mais poderosas para o teatro nacional.

\section{Terceira etapa: operetas e revistas de ano brasileiras}

Após experimentar as adaptações de operetas, Arthur Azevedo passou a escrever peças originais, musicadas por compositores brasileiros ou lusobrasileiros. Em 1880 ele escreveu Os noivos e A princesa dos cajueiros, com músicas de Francisco de Sá Noronha (1820-1881). Noronha, nascido em Portugal, mudou-se para o Brasil com 18 anos de idade. Como outros compositores de operetas da época, ele misturava um aprendizado em música erudita com o conhecimento da música popular: "Compositor de inúmeros lundus, modinhas, polcas, quadrilhas [...]. Tornou-se um dos pioneiros no uso de temas folclóricos brasileiros em canções para teatro."16 Ambas foram encenadas por Jacinto Heller e tiveram Henrique Mesquita (1830-1906), maestro brasileiro, regendo a orquestra.

Essas peças seguiam a estrutura da opereta francesa: a divisão das cenas, a alternância entre partes cantadas e faladas, o ritmo dinâmico, grande número de personagens, ironia e críticas aos costumes e à política. A diferença entre elas e as adaptações anteriores consiste no enredo original inteiramente fundamentado na cultura e na música nacionais. As operetas originais tinham tramas totalmente novas, baseadas em hábitos dos brasileiros e/ou em sua história e questões políticas e sociais. Muito importante também para diferenciá-las das adaptações: a música era original e composta por artistas da terra, que compunham entrelaçando os ritmos eruditos, mas saltitantes, das operetas europeias com

${ }^{16}$ https://dicionariompb.com.br/francisco-de-sa-noronha/dados-artisticos Acesso em: 02 maio 2021. 
ritmos populares nacionais.

Os noivos aborda os costumes da roça, passa-se em uma fazenda, e o enredo gira em torno dos quiproquós de três casais até o casamento, havendo ciranda e troca de pares, até cada qual terminar prometido em casamento com quem deveras gosta. Sendo uma trama ingênua e típica de comédias, a tessitura da opereta ganha vida e ganha em crítica quando coloca em cena as pessoas escravizadas da fazenda. Os escravos surgem nos números musicados, seja para rezarem a ladainha à Nossa Senhora junto com seus senhores, revelando o aspecto de catolicização da população, seja para dançarem o cateretê e o jongo, revelando a resiliência da religião e da cultura afro-brasileira. Além disso, existe uma passagem cantada que se refere diretamente aos partidos políticos e à queda de ministérios. Nesses momentos, a crítica política ganha contornos evidentes.

Já em $A$ princesa dos cajueiros a crítica surge em forma de parábola. A criação da personagem El-rei Caju, rei na ilha imaginária Caju, onde a história se passa, é baseada na personalidade e na forma como as pessoas viam o imperador brasileiro da época, Dom Pedro II. A analogia ao mesmo tempo que tornava a crítica manifesta ao público também a protegia da censura, recurso que seria utilizado, pouco menos de cem anos depois, pelos artistas que lutavam contra a ditadura, nos musicais políticos, que comentaremos rapidamente mais adiante.

Além das operetas brasileira, surgem a partir da década de 1880, mais precisamente a partir de 1884, as revistas de ano brasileiras. Depois de algumas tentativas infrutíferas de encenar revistas no Rio de Janeiro, o gênero finalmente alcançou sucesso após uma viagem de Arthur Azevedo à Europa. Em Paris, o autor pode assistir in loco aos espetáculos musicados. Não é coincidência que no ano de seu retorno escrevesse, junto com Moreira Sampaio, a primeira revista de ano a ter êxito no país: O Mandarim (Veneziano, 1996).

A revista de ano, por estar ainda mais estreitamente ligada à realidade social e cultural de uma região, dificilmente obtém entendimento de público se encenada em outros locais que não aquele no qual ela se criou. A opereta ganhou o mundo por assumir enredos que, embora fragmentados, compõem uma fábula traduzível em outros idiomas e culturas. A revista de ano, sem fábula, ou com uma 
fábula muito frágil, sustenta-se pelas alusões aos acontecimentos reais do ano que passou. O gênero tem também origem francesa e as revistas encenadas aqui eram brasileiras, mas sem ainda conjugar um gênero de teatro novo.

Assim como as operetas brasileiras, a ordenação da cena das revistas de ano, até o final do século XIX, continuava a ser aquela na qual Arthur Azevedo se inspirou para elaborar O Mandarim e todas as outras que se seguiram (o autor escreveu 19 revistas-de-ano ao longo de sua carreira, várias em parceria com Moreira Sampaio). Os números musicados, as danças, as corporeidades nacionais, aos poucos colocariam, porém, e cada vez mais fortemente, em xeque aquelas estruturas cênicas. Naquele momento, porém, anos 1880 e anos 1890, ainda podemos dizer que o teatro musicado no Rio de Janeiro seguia os parâmetros estéticos daqueles gêneros europeus, conquanto cada vez mais a carga de brasilidade levasse a rupturas e subversão das convenções inicialmente adaptadas, abrasileiradas.

Diversos outros autores dedicaram-se aos chamados gêneros ligeiros ${ }^{17}$. Junto a Arthur Azevedo e Moreira Sampaio destaca-se o nome de Eduardo Garrido (1842 - 1912) como escritor de operetas e revistas originais. Português, este dramaturgo, cuja obra e importância para nossa história ainda está para ser desvendada ${ }^{18}$, escreveu inúmeras peças, baseadas tanto na cultura portuguesa como na brasileira. Alguns dos compositores que trabalharam com esses autores, além de Sá Noronha, na criação textual e musical das obras foram Abdon Milanez (1858 1927) e o já citado Henrique Mesquita19.

\section{Quarta etapa: surgem os gêneros nacionais}

Entre o final do século XIX e começo do XX podemos dizer que se estruturaram gêneros nacionais, novos; gêneros que são um deslindar dessa

\footnotetext{
${ }^{17}$ O termo "gênero ligeiro" se refere a diversas formas de teatro de entretenimento, as operetas e revistas são de gênero ligeiro, mas também zarzuelas, burletas, vaudevilles, teatro de variedades, entre tantos outros.

18 Tenho uma orientanda de doutorado que está pesquisando a obra do autor.

Para mais informações, ver: https://dicionariompb.com.br/abdon-milanez/dados-artisticos; https://dicionariompb.com.br/henrique-alves-de-mesquita/dados-artisticos

Acesso em: 02 maio 2021.
} 
caminhada. Importante salientar que as etapas, descritas aqui de maneira didática, servem para estabelecermos alguns parâmetros teóricos e históricos porque, obviamente, a caminhada se fez num continuum, sem que nada obviamente desparecesse quando as demais surgiam.

Convencionou-se chamar o gênero brasileiro que se desenvolveu a partir do estabelecimento dos gêneros musicados nos palcos nacionais de burleta. $\mathrm{O}$ termo é usado por Rubens Brito (1989), em dissertação sobre a obra de Arthur Azevedo, mas também surge nas peças publicadas na época e em outros estudos históricos (Faria, 2012). Usar a palavra burleta enfatiza o fato de que os espetáculos não consistiam mais em uma adaptação de um gênero estrangeiro, a opereta, mas sim em algo que não tem mais respaldo naquela convenção. Aos poucos, passo a passo, a burleta se constitui, e, embora se possam verificar semelhanças entre a burleta, brasileira, e a opereta, francesa, as diferenças formais são suficientes para que se tratem de novas convenções cênicas, de uma nova linguagem.

A burleta é um gênero de teatro musical brasileiro que é uma transformação, uma consequência, não só das operetas, mas de outros gêneros teatrais populares como a revista de ano, as comédias de costumes, as mágicas ${ }^{20}$. Rubens Brito (1989) classificou cinco peças de Arthur Azevedo como sendo burletas. Peças de maturidade do autor, tais obras de fato não podem ser mais consideradas de acordo com os gêneros musicados franceses que uma vez aportaram ao Rio de Janeiro. Destas cinco, as duas mais intricadas e expressivas foram $A$ Capital Federal, de 1897, e O Mambembe, de 1904. Verdadeiras obras primas dramatúrgicas, revelam a complexidade imensa, seja de uso da língua e do cotidiano nacional, seja da estrutura dramática, da burleta nacional (Cf. suprimido por revelar autoria). A primeira fora diretamente inspirada na revista de ano que o autor escrevera sobre o ano de 1891 (O Tribofe), ambas trazem uma nova carpintaria cênica que não se aproxima mais nem da revista de ano, nem da opereta, nem da mágica, era algo novo que surgia: a burleta.

No começo do século XX as burletas irão se espalhar pelos teatros do Rio de Janeiro e de São Paulo. Um exemplo importante da configuração deste gênero é

${ }^{20}$ Gênero teatral fantástico que explora a mudança de cenário como principal convenção. 
a peça Forrobodó, de 1912, escrita por Luiz Peixoto (1889-1973) e Carlos Bettencourt (1890-1941) e musicada por Chiquinha Gonzaga (1847-1935). Foi encenada pela companhia Paschoal Segretto (1868-1920) e chegou a 1500 apresentações, segundo a publicação da Revista de Teatro da SBAT(Peixoto; Bettencourt, 1961). A peça é fundamental para a reflexão sobre a realidade da época, sobre o racismo, o preconceito contra a cultura brasileira e popular, explorando a dualidade de representar a população negra, mas tendo sido escrita por pessoas brancas (Cf. Lopes, 2006).

Essa peça, como as burletas em geral, se expande numa fábula sem andamento linear. Não interessa, na burleta, um enredo em que se vise a uma progressão dramática, em que se vise a captar o público para que este fique curioso em "saber o que vai acontecer". Não é esse foco, dramático, o foco de interesse das burletas - sua base formal está na espetacularidade, e esta é toda calcada no imaginário nacional, nas linguagens cênicas brasileiras. Portanto, aquelas referências à opereta e à revista de ano, mesmo abrasileiradas, e cada vez mais abrasileiras, tornaram-se um gênero novo.

A peça se pauta intensamente na performatividade popular nacional, só podendo ser entendida e encenada pelas linguagens brasileiras de teatralidades. Os diálogos são mote para a corporeidade, a dança, a expressividade da cultura popular e para os números musicais que os seguem. A peça se passa, na primeira parte, na rua, em frente ao clube onde haverá uma festa. Temos o início com um coro animado, repleto de palavras brasileiras: "que barulho"; "sarrabulho"; "rebuliço"; "bateu asas e avuou” (Peixoto; Bettencourt, 1961, p.4). São várias figuras, vozes, coros. A segunda parte se dá durante a festa, onde ocorrem desavenças, discurso, danças e cantoria, duetos, solos e mais cantoria coral. A segunda parte termina com o povo saindo para o bufete: "Vamos ao vinho, à bagaceira e às empadinhas de camarão! Vamos às papas, ao porco assado, e à feijoada de estimação!" (Peixoto; Bettencourt, 1961, p.9).

Na terceira parte, observamos a chegada de Lulu, capoeirista, cuja atuação se volta àquela manifestação cênica popular, entre dança, luta e jogo: Lulu "ajeita o cinto com passos de capoeira" (Peixoto, Bettencourt, 1961, p.10); há um momento de leilão (sempre presente na festa popular). O coro final chama pelo maxixe: 
"Pessoal, está na hora da festança terminar, mas antes d'irmos embora toca tudo a maxixar!" (Peixoto; Bettencourt, 1961, p.14).

Para a caminhada analisada aqui, cabe constatar que as burletas têm uma formatação própria, elas são baseadas integralmente nas linguagens cênicas populares nacionais; conversam, como teatro de palco que são, com aquelas formas teatralizadas comentadas na primeira etapa deste traçado. Uma burleta como Forrobodó é feita de danças, corpos, linguagens, música nacionais. Se há, e esse é um problema ainda não resolvido do nosso país, uma estereotipação de personagens populares e negras, há também uma inovação formal constitutiva daquela cena, que não observa o estrangeiro, que não quer ser parecida com o europeu. Ela parte da observação de costumes da cidade do Rio de Janeiro - suas músicas, suas festas, seus modos de interagir. A música é feita de maxixe, de batucada, de sensualidade.

Diversas peças com forma semelhante foram encenadas até a segunda metade do século $X X^{21}$. A concepção de cena estava cada vez mais distante daquelas referências francesas oitocentistas e cada vez mais próxima da cultura de rua que nunca abandonou as ruas, mas que, junto com as ruas, ganhava então também vida nos palcos. No caso das revistas de ano o processo foi semelhante. Elas se tornaram, com o tempo, livres daquele formato convencional oriundo da Europa, que tinham no século XIX. Tal liberdade na composição dos quadros leva a revista a ganhar uma formatação única, ao incluir, projetar e conversar cada vez mais profundamente com a festa popular. A aproximação com a linguagem cênica da festa é tão arraigada que Neyde Veneziano (2013) denomina a nova forma de revista carnavalesca. As revistas continuam referenciando a realidade, criticando a sociedade e a política em números humorísticos, ao mesmo tempo revelam expressivamente a música e dança brasileiras como configuração cênica: é a revista brasileira.

\footnotetext{
${ }^{21}$ Alguns exemplos podem ser encontrados em Rabetti, 2007.
} 


\section{Epílogo ou: ninguém acorrenta a teatralidade nacional}

As quatro etapas delineadas acima apontam para uma constituição de formalidades nacionais de cena, linguagens cênicas brasileiras, muitas, variadas, todas relacionadas com a música e a dança de alguma forma, sejam as linguagens dos folguedos e festas, sejam as linguagens do teatro de palco. O teatro de convenção passa, a partir da segunda metade do século XX, a conviver com o teatro moderno, que, entre outras características, não segue convenções, mas trabalha com elas, reinventando-as, subvertendo-as, quebrando-as. O teatro moderno brasileiro, além de romper com o drama, o gênero teatral literário europeu, trabalha também com convenções das linguagens nacionais.

Da mesma forma como alguns dramaturgos oitocentistas, como Francisco Vasques, Martins Pena e Arthur Azevedo, perceberam o manancial de teatralidades no qual poderiam beber para criar suas peças, sem precisar se respaldar em referências estrangeiras, o mesmo acontece no século XX, seja no teatro que continua a ser convencional (o das burletas e revistas), seja no teatro moderno. Se num primeiro momento, anos 1950, o teatro moderno se faz sem música, não demora para os artistas desta linguagem também perceberem o que estão perdendo em não se aventurar a trabalhar com a potência do musical brasileiro. Assim, a partir dos anos 1960 temos a criação de uma série de musicais com uma outra conformação, não são mais revistas e burletas, mas sim os chamados musicais modernos políticos que se instauram no cenário teatro de São Paulo e do Rio de Janeiro. Musicais de unicidade em cada composição, mas que se inspiravam vivamente das formas revisteiras de seus antecessores.

Nas décadas seguintes os musicais se renovaram de diferentes formas. Continuaram a ser produzidos o que podemos chamar de musicais modernos ou contemporâneos, aqueles que partem de pesquisa de grupos, de motes para a criação de espetáculos específicos; junto com eles, musicais de convenção também se tornaram cada vez mais presentes nas capitais do sudeste, como as traduções de musicais West End e Broadway. Trata-se de uma outra e nova vertente que começa a ser pesquisada muito recentemente. 
O fato é que, quando se olha para o passado, e para o presente, difícil a gente entender porque a historiografia teatral ficava tão presa à procura do drama nacional, seja o romântico, seja o realista, seja o moderno, quando o teatro vivo estava se desenvolvendo sem peias ao nosso redor, o teatro musicado, não dramático, fragmentado, comunicativo, intenso.

Da Opereta carioca ao Teatro de Revista, do musical político e engajado de Chico Buarque, por exemplo, à importação de espetáculos da Broadway e os espetáculos musicais biográficos, a sociedade brasileira convive há mais de um século com esse estilo musical de fazer teatro. Cada época a sua maneira, com suas problemáticas, com seu estilo. No entanto, apesar de a cena musical existir no Brasil há muitos anos, ela ainda é relativamente nova e está, hoje, em um momento de expansão e assimilação por parte do público, da crítica e também dos profissionais envolvidos (Sousa; Silveira; Toletino, 2018, p.160).

A citação acima parece contraditória quando afirma que sempre convivemos com os musicais e ao mesmo tempo essa é uma cena "relativamente nova". Mas a contradição faz parte das nossas formas de pesquisar e pensar o teatro brasileiro. A novidade talvez esteja nessa nova forma de olhar, de enxergar, de ver o teatro musicado brasileiro como algo positivo, complexo, artisticamente interessante. A novidade talvez esteja na pesquisa acadêmica e universitária abrirse para observar, analisar, pensar sobre formas populares de arte sem os cabrestos dos preconceitos letrados, brancos, coloniais.

Na verdade, o teatro nacional sempre se fez musicado: na rua, na festa, no terreiro, na praça... e no palco. É um teatro que sempre foi performático, fragmentado, épico, desde que o Brasil começou a se formar. É um teatro que sempre esteve à frente de teorias ou tentativas de modernização. É um teatro que nunca seguiu os críticos que buscavam teorizar, formular, e colocar a cena presa em uma caixa preta e suas quatro paredes. É o teatro bagunça ${ }^{22}$ brasileiro.

\section{Referências}

ABREU, Márcia; DEAECTO, Marisa Midori (org.). Circulação transatlântica dos

22 Para citar, de novo, porque nunca é demais lembrar dele, o conceito de Alcântara Machado (2009, p. 377). 
impressos [recurso eletrônico]. Campinas - SP: Unicamp/IEL/Setor de Publicações, 2014. Disponível em:

https://issuu.com/marciaabreu/docs/circulacao_transatlantica_dos_impre Acesso em: 01 out. 2019.

ABREU, Martha Campos. O império do Divino: festas religiosas e cultura popular no Rio de Janeiro (1830-1900). Tese (Doutorado em História) - IFCH, Universidade Estadual de Campinas, Campinas, 1996.

ALENCAR, José de. A comédia brasileira. Diário do Rio de Janeiro, 14 de setembro de 1857.

ALMEIDA, Paulo Roberto de. A presença negra no teatro de revista dos anos 1920. Dissertação (Mestrado em História Social) - Universidade Federal Fluminense, Niterói, 2016.

ANDRADE, Mário. Danças dramáticas do Brasil. 3 vols. 2. ed. Belo Horizonte: Itatiaia / INL, 1982.

AZEVEDO, Artur. Teatro de Artur Azevedo. Rio de Janeiro: Funarte, 2002.

BRITO, Rubens José de Souza. A linguagem teatral de Artur Azevedo. Dissertação (Mestrado em Artes Cênicas) - Escola de Comunicações e Artes, Universidade de São Paulo, São Paulo, 1989.

BRUYAS, Florian. Histoire de l'opérette en France. Emmanuel Vitte, 1974.

CASCUDO, Câmara. Dicionário do folclore brasileiro. 11. ed. São Paulo: Global, 2002.

CHIARADIA, Filomena. A Companhia do Teatro São José: a Menina-dos-Olhos de Paschoal Segreto. São Paulo: Hucitec, 2012.

COSTA-LIMA NETO, Luís de França. Música, teatro e sociedade nas comédias de Luiz Carlos Martins Penna (1833-1846): entre o lundu, a ária e a aleluia. Tese (Doutorado em Música) - Universidade Federal do Estado do Rio de Janeiro, Rio de Janeiro, 2014.

DURTREUTRE, Benoît. L'opérette en France. Paris: Fayard, 2009.

FARIA, João Roberto. Ideias teatrais: o século XIX no Brasil. São Paulo: Perspectiva, 2001.

FARIA, João Roberto (dir.). História do teatro brasileiro. São Paulo: Perspectiva/SESC-SP, 2012.

FARIA, João Roberto. O teatro realista no Brasil: 1855-1965. São Paulo: Perspectiva, 1993.

FERREIRA, Aléxia Lorrana Silva. Jacinto Heller: Repertório de um empresário teatral 
(1875-1885). Cadernos Letra e Ato, Campinas, v.6, Jul., 2016. Disponível em: https://www.publionline.iar.unicamp.br/index.php/letraeato/article/view/585/551. Acesso em: 30 abr. 2021.

FONTENELE, Wesley. O Bumba-meu-Boi de Parnaíba (PI) em diferentes espaços: a rua, a arena e as lives juninas. Urdimento - Revista de Estudos em Artes Cênicas, Florianópolis, v. 2, n. 38, ago./set. 2020. Disponível em:

https://www.revistas.udesc.br/index.php/urdimento/article/view/18089/11926 Acesso em: 03 jun.2021

FREYRE, Gilberto. Casa grande e senzala: formação da familia brasileira sob o regime da economia patriarcal. Rio de Janeiro: José Olympio, 1973.

GUINSBURG, J; FARIA, João Roberto; LIMA, Mariângela Alves de. Dicionário do teatro brasileiro: temas, formas, conceitos. São Paulo: SESC/SP; Perspectiva, 2006.

HOLANDA. Sérgio Buarque. Raízes do Brasil. 26a ed. São Paulo: Companhia das Letras, 2014.

LEVIN, Orna Messer. Offenbach e a disputa pelo público brasileiro (1840-1870). In: ABREU, Márcia; DEAECTO, Marisa Midori. A circulação transatlântica dos impressos [recurso eletrônico]. Campinas: IEL, Unicamp, Setor de Publicações, 2014, p. 299310. Disponível em:

https://issuu.com/marciaabreu/docs/circulacao_transatlantica_dos_impre. Acesso em: 28 maio 2021

MACHADO, Antônio de Alcântara. Palcos em foco: crítica de espetáculos / ensaios sobre teatro (1923-1933), tentativas no campo da dramaturgia. São Paulo: Edusp, 2009.

MACIEL, Paulo, RABETTI, Maria de Lourdes. O teatro de opereta no Brasil: gênero e história. In: Anais do Encontro Nacional da ANPUH, Rio de Janeiro, 2010. Disponível em:

http://www.encontro2010.rj.anpuh.org/resources/anais/8/1276743123_ARQUIVO_te xto_para_publicacao___Paulo_MacieleMariadeLourdesRabetti.pdf

Acesso em: 30 abr. 2021.

MAYOR, Mariana Soutto. O teatro do século XVIII no Brasil: das festas públicas às casas de ópera. Revista Aspas, São Paulo, v. 5, n.2, jul., p. 103-110, dez. 2015.

MAYOR, Mariana Soutto. A Casa da Ópera de Vila Rica através do estudo de duas cartas de João de Souza Lisboa. Sala Preta, São Paulo, v.17, n.2, p. 236-248, 2017.

MENCARELLI, Fernando Antonio. Cena aberta: a absolvição de um bilontra e o teatro de revista de Arthur Azevedo. Campinas - SP: Editora da Unicamp, 1999.

MENCARELLI, Fernando Antonio. A voz e a partitura: teatro musical, indústria e diversidade cultural no Rio de Janeiro (1868-1908). 2003. Tese (Doutorado em História) - Universidade Estadual de Campinas, Campinas, 2003. 
NAVARRO, Grácia; Martini, Andréa. Carnaval Brasileiro: do legado colonial à pluralidade de linguagens na contemporaneidade brasileira - o caso do Bloco BerraVaca! In: CRUZ, Hugo; BEZELGA, Isabel; RODRIGUES, Paulo Simões (org.). Práticas artísticas comunitária. Porto: PELE - Espaço de Contacto Social e Cultural; CHAIA - Centro de História da Arte e Investigação Artística da Universidade de Évora; FCT - Fundação para a Ciência e a Tecnologia, p. 351 - 366, 2017.

NEVES, Larissa de Oliveira. A opereta francesa: alguns apontamentos para compreender sua história. Ephemera, Ouro Preto, v. 1, n. 1, p. 41-60, dez. 2018. Disponível em: https://periodicos.ufop.br/ephemera/article/view/1662 Acesso em: 30 abr. 2021

NEVES, Larissa de Oliveira. A filha de Maria Angu e a cultura popular no teatro oitocentista. Cadernos Letra e Ato, Campinas, v. 6, n. 6, jul. 2016. p. 42-53. Disponível em:

https://www.publionline.iar.unicamp.br/index.php/letraeato/issue/view/40/showT oc Acesso em: 30 abr. 2021.

NEVES, Larissa. As comédias de Artur Azevedo: em busca da história (1894-1908). 2006. Tese (Doutorado em Teoria e História Literária) - Universidade Estadual de Campinas, Campinas, 2006.

PEIXOTO, Luiz; BETTENCOURT, Carlos. Forrobodó. Revista de Teatro. SBAT. Rio de Janeiro, n. 322, jul.-ago.,1961.

PRADO, Décio de Almeida. A evolução da literatura dramática. In: COUTINHO, Afrânio (org.). A literatura no Brasil. 2a ed. Rio de Janeiro, RJ : Sul Americana, 19681971. p. $7-17$.

PRADO, Décio de Almeida. História concisa do teatro brasileiro. São Paulo: Perspectiva, 1999.

RABETTI, Beti. Teatro e comicidades 2: modos de produção do teatro ligeiro carioca. Rio de Janeiro: 7 Letras, 2007.

RIBEIRO, Darcy. O povo brasileiro: a formação e o sentido do Brasil. 2[ ed. São Paulo: Companhia das Letras, 1995.

SCHWARCZ, Lilia M.; STARLING, Heloisa M. Brasil: uma biografia. São Paulo: Companhia das Letras, 2015.

SIMAS, Luiz Antonio. O corpo encantado das ruas. 6a ed. Rio de Janeiro: Civilização Brasileira, 2020.

SOUSA, Raimundo Expedito dos Santos; SILVEIRA, Éderson Luís; TOLENTINO, Magda Veloso Fernandes de. Do Teatro de Revista às incorporações da Broadway em palcos tupiniquins: singularidades, inspirações e desafios na história do Teatro Musical brasileiro. Revista Letras Raras, Campina Grande, v. 7, n.1, p. 159-182, 2018. 
Disponível em: http://revistas.ufcg.edu.br/ch/index.php/RLR/article/view/887 Acesso em: 09 fev. 2021.

VENEZIANO, Neyde. Não adianta chorar: teatro de revista brasileiro... Oba!. Campinas, SP: Unicamp, 1996.

VENEZIANO, Neyde. O teatro de revista no Brasil: dramaturgia e convenções. 2. ed. São Paulo, SP: SESI (São Paulo), 2013.

VENEZIANO, Neyde. Teatro Musical: da tradição ao contemporâneo. Revista Poiésis. Niterói, n. 16, p. 09-11, dez. 2010. Disponível em:

https://periodicos.uff.br/poiesis/article/view/26967/15671 Acesso em: 22 fev. 2021

Recebido em: 04/06/2021

Aprovado em: 12/08/2021 